\title{
Resolving a Teacher-Student Conflict: An Intrinsic Case Study
}

\author{
Atara Isaacson ${ }^{1}$ \\ ${ }^{1}$ A School of Education, Bar Ilan University, Ramat Gan, Israel \\ Correspondence: Atara Isaacson, A School of Education, Bar Ilan University, Ramat Gan, 5290002, Israel. \\ E-mail: isaacsa@biu.ac.il
}

Received: October 20, 2015 Accepted: November 1, 2015 Online Published: December 15, 2015

doi:10.5539/jel.v5n1p68

URL: http://dx.doi.org/10.5539/jel.v5n1p68

\begin{abstract}
This article presents an episode that occurred during a semester-long academic course called: Conduct Problems and Class Navigation. It focuses on investigating the behavior of a student who, because of her uniqueness, was an interesting candidate for an intrinsic case study. This paper presents a distinctive way of handling an interfering and disruptive student in an academic course at the university. The description of the case takes the reader on a narrative journey and demonstrates a solution for the inappropriate behavior. The lecturer's persistent and consistent use of the bypass procedure demonstrates an on-site application of a teaching tool and her response influenced the student's behavior and achievement. This also caused the other students to be aware of basic rules concerning class conduct.

The lecturer's conduct in this case can contribute to beneficial conduct during academic teaching. The novelty here is in the lecturer's modeling approach, which allows students to experience firsthand, a way of disciplinary problem solving which they can use with their future students.
\end{abstract}

Keywords: ideological/interpersonal conflict, conduct, teacher-student relationship, intrinsic case study, class navigation, didactic strategy, teacher education

\section{Introduction}

A considerable challenge in teaching is the responsive relationship created between the teacher and student during the lesson (Baker, 2008; Belton, 2008; Gordon et al., 2007; Bradley et al., 2005; Greer, 2002; Olsen, 2001; Skinner \& Belmont, 1993). There are certain incidents that happen in the classroom that cannot be taught or prepared for in university or college teaching programs (Barnett et al., 2010; Scott \& Teale, 2010; Sykes et al., 2010; Schelfhout et al., 2006). As McNaughton-Cassill (2013) argues, managing behavior in the classroom can be one of the most challenging tasks a faculty member undertakes. Whether students are engaging in incivility because they are stressed, bored, rebellious, or experiencing a mental illness, faculty still bear the responsibility for responding to the student appropriately, getting them help if necessary, and continuing to provide a comfortable learning environment for other students'. Nevertheless, in most teaching programs there is a course dealing with navigating the interactive flow in a classroom and the problems therein. Such a course intends to supply student teachers with tools that will facilitate their interactions with pupils of different ages, personalities, backgrounds, beliefs, and social development levels.

This article presents a unique episode that occurred during a university course called Conduct Problems and Class Navigation. During the course, I unintentionally demonstrated a solution, or an on-the-spot demo, to the rude and inappropriate behavior of a student teacher. Since there is an immediate correlation between student-teacher relationships and student outcomes (Deker et al., 2007; Stronge et al., 2007), I realized at the end of the course that my reaction and attitude actually influenced the student's behavior and achievements and caused the other students to be aware of basic rules concerning class conduct.

Since the incident happened while teaching, it became a kind of an impromptu research study. Even though each case and situation is exclusive, being heavily dependent on the personality of both teacher and student, I realized this could be a useful case study and perhaps others could apply this approach as a method of dealing with similar problems. 


\section{Research Method}

This kind of research method is an ex post facto research, which can be viewed as an experimental research in reverse. According to Simon and Goes (2013), ex post facto research is ideal for conducting social research when is not possible or acceptable to manipulate the characteristics of human participants. It is substitute for true experimental research and can be used to test hypotheses about cause-and effect or correlational relationships, where it is not practical or ethical to apply a true experimental, or even a quasi-experimental design.

Despite studying facts that have already occurred, ex post facto research shares with experimental research design some of its basic logic of inquiry. For example, attempts are made to explain a consequence based on antecedent conditions or determine the influence of a variable on another variable. Upon conclusion of the course (that will be described in the next chapter), I realized that such a "behavior solution" could applied again in other events that might occur between student and a lecturer in the classroom. Cohen, Manion and Morison (2000), noted that an ex post facto experiment begins with groups (individuals in our case), that are already different in some respect and searches in retrospect for factors that are brought about those differences. That last insight makes it even more reliable and valid.

The incident described in this article falls into the category of an intrinsic case study (Stake, 1995). As Stake states: "we are interested in it not because by studying it we learn about other cases or about some general problem, but because we need to learn about that particular case" (p. 3). It differs from a situation in which we have a research question, a need for a general understanding, and feel that we may gain insight into the question by studying a particular case, named an instrumental case study (Ibid). Instead of looking for the problem that is the object of the research, in the intrinsic case we encounter the problem by chance.

My challenge here is to describe the case and take the reader on a narrative journey, similar to On the Bus with Vonnie Lee (Angrosino in Creswell, pp. 257-269), or Campus Response to a Student Gunman (Asmussen \& Creswell, pp. 357-374). This article calls for an explication of the problem (the aggressive attitude of a student-teacher in an academic course), a thorough description of the context and the process observed (her behavior, comments and colleagues' responses), a discussion of important elements (my reaction and feedback), and finally "lessons to be learned" (Creswell, p. 221), the preferable mode of relationship between a lecturer and student in an academic institute.

\subsection{The Course}

"Navigation in the Classroom and Solving Discipline Problems" is a one-semester required course for students taking the Teaching Certificate Program at the university's School of Education. There are approximately 100 students from a variety of disciplines (Math, Music, Bible, Chemistry, Arabic, English, Literature, etc.). The course's objectives are: 1) Familiarization with efficient methods of coping with daily interactions between teachers and pupils at elementary and secondary schools. 2) Enabling teachers to recognize their authority as teachers. 3) Introducing teachers to methods that reduce physical and verbal hostility in the classroom and within the school environment.

The course is based on a qualitative research study which was conducted by the author (Isaacson, 2010) imparting the Ten Commandments guideline for a productive dialogue between teachers and pupils. Data for the research was collected in three modes: observing lessons, conducting structured interviews (Silverman, 2000; Merriam, 1998; Bogdan \& Biklen, 1982) and filling out an open-ended questionnaire.

The findings of the research were arranged in the format of The Ten Commandments and were divided into three main categories: professionalism, humaneness and compassion, and control and rules. A fourth category, reciprocity, served as a summation of the entire Ten Commandments. The course "Navigation in the Classroom and Solving Discipline Problems" applies the recommendations specified in the Ten Commandments through modeling, where the lecturer teaches and behaves according to the recommendations without notifying the students in advance. This teaching method is based on research that suggests that learning with self-explanatory examples is an effective method in well-structured domains (Green, Mitchell, \& Taylor 2011; Valentine, 2011; Schworm \& Renkl, 2007). That way, students experience a real-time demonstration and get on-the-spot evidence as to what conduct works and what conduct does not.

The course's main goal is that student teachers better understand the delicate teacher-pupil relationship. It offers methods for listening, effective confrontation and behavior management. Most examples are presented as role playing, analyzing strategic reactions of teachers, and emphasizing the connection between a pupil's self-image and his ability to function in the classroom. The preferable mode for such a course is a workshop with a limited number of participants. Unfortunately, in this particular course, there were more than 90 students and the 
allocated time was not sufficient to share all the experiences in a weekly lesson of an hour and a half. Therefore, we used the course's internet site to discuss unresolved issues.

\subsection{Ethical Considerations}

This article documents a chain of responses that occurred unintentionally during the course. This is different from a regular case study. Normally a case study is an intensive, prolonged examination of a single person or organization, using multiple sources and types of data, such as documents, observations, and interviews. The data is systematically collected and analyzed. In this manuscript, the data consist of my personal reactions and responses to Shelli's behavior (that will be described later). Despite the different environment and personalities of the teacher and student, the lessons can be generalized because the behaviors displayed are hardly unique. The reactions and expressions were spontaneous and took place in public in front of the students. None of these events occurred in personal meetings. I made sure to blur all identifying details concerning the student teacher. My reactions were educational-didactic and were an outcome of unplanned circumstances. I subsequently realized that these interactions were good impromptu examples of how to deal with inappropriate behavior. I took as many steps possible to protect the individual's rights and welfare and I made sure that her identity was not revealed.

The university in which this took place is a large university with a student population of approximately 34,000 students. The School of Education at the university has over 2,000 students who come from all walks of life and from many sectors of the population. In addition, the described course is given every semester. These facts make identification of the individual described virtually impossible.

\subsection{Background}

Shelli (pseudonym), a middle-aged Jewish ultra-orthodox student, was one of the participants in this heterogenic group. Shelli behaved in a not acceptable way. She talked loudly when she did not agree with the lecturer. She read articles, marked papers or dealt with other things during the lecture and expressed her opinion without being granted permission to do so.

Let me say a few words about the university's background in comparison to Shelli's background. The university regards the sacred principles of Judaism as the manifestation of the Jewish people's uniqueness, in accordance with the principles defined upon its establishment. The university's basic goals include supporting and safeguarding these principles with the purpose of training and producing scholars, researchers and scientists knowledgeable in the Torah and imbued with the original Jewish spirit and love of one's brethren. The university cultivates and combines Jewish identity and tradition with modern technologies and research. The university's student body is of diverse cultural and religious backgrounds. They study together in classrooms, laboratories and libraries, and thus this university contributes to tolerance and coexistence among students who are religious and secular, Arab and Jewish.

Shelli belongs to the Haredi community. Haredi Judaism is the most conservative form of Orthodox Judaism, often referred to as ultra-Orthodox (Heilman, 2000). The word Haredi, which was the original Hebrew translation of Orthodox (Ibid), is derived from the word harada, which in the context of Orthodoxy means "one who trembles in awe of God" (Isaiah 66:2). There are currently approximately 1.3 million Haredi Jews worldwide, and they are one of the fastest growing demographic sectors in Judaism (Ibid). Haredi life is very family-oriented. Depending on various factors, boys and girls attend separate schools and proceed to higher Torah study, in a yeshiva or seminary respectively.

Haredi rabbis frown upon watching television and films, reading secular newspapers and using the internet without filters that block pornographic sites and the likes. They also use mobile phones whose internet and other functions that could influence their users in undesired ways are disabled. Many Haredim have a distinct dress code. They view it as an important way to ensure Jewish identity and distinctiveness. In addition, a simple, understated mode of dress promotes their inner reflection and spiritual growth. As such, many Haredim are wary of modern clothing. Many men grow beards, most dress in dark suits, wear a wide-brimmed hat (typically black) during prayer and a black kippah (skullcap) at all times. Women adhere to meticulous modesty standards, and hence wear long skirts and long sleeves, high necklines and if married, some form of head covering: scarves, snoods, hats, or sheitels (wigs).

Israel has the largest Haredi population of approximately 736,000 (out of 7 million Israeli Jews) (BBC), and their numbers are increasing quickly. Only a generation ago, in 1992, of the 1,500,000 Orthodox Jews living worldwide, about 550,000 were Haredi, half of them living in Israel (Baumel, 2005). The vast majority of Haredi Jews are Ashkenazi (of European descent). However, about $20 \%$ of the Haredi population belongs to the 
Sephardic (North African and Levant descent) Haredi stream. The Haredi community in Israel has adopted a policy of cultural dissociation, but at the same time, has struggled to remain politically active, perceiving itself as the true protector of the country's Jewish identity. In both secular and religious education programs, the situation of an overt ideological clash over "fundamentalism" of sorts is quite predictable.

Following are some scholars that examined the correlation between religious students and class conduct. Marzluf (2009) examined the post-secondary transition of six predominantly home-schooled students who profess the importance of their Christian faith. The author analyzed their writing to find out how they negotiate between their religious ideologies and their post-secondary education. His findings show that while the formerly home-schooled study participants demonstrated that they could adjust smoothly to the expectations of the university, it was the secular faculty who much too enthusiastically attempted to transform the students' social values as well as their degree of commitment to the college community. Lichtmann (2010) suggests that contemplative teaching can offer both teachers and students a middle ground between two reigning fundamentalisms: the secularist one of nonadvocacy, relativism, and equivocation and the forced univocity of fundamentalism. She explores the potential of an impasse to be a contemplative space for reflection and transformation and the potential of the community college to turn impasse into invitation.

Boice (1996) does not find any correlation between disruptive classroom behaviors and religion issues. He summarizes a five-year study of Classroom Incivilities (CI) at a large research university. In systematic observations of large survey courses, he ranked the most problematic CI as (1) teachers displaying aloof, distancing mannerisms; (2) teachers discouraging student involvement with fast-paced lectures; (3) students' noisiness and indifference; (4) students coming late and leaving early; (5) students' sarcastic remarks/gestures; and so on. High levels of CI correspond to low levels of student attentiveness and note taking, and to low levels of teacher enthusiasm, clarity/organization, and immediacies (i.e., expressions of warmth and approachability). High CI means fast-paced lectures, student confusion/annoyance, and perceptions of teachers as uncaring and incompetent. The key initiator of CI may be teachers' deficits in immediacies, particularly during the first few days of classes. McNaughton-Cassill (2013) posits that rising rates of incivility in the college classroom can generate stress for both faculty and students. However, incivility can take multiple forms, have different causes and require different management techniques. In some cases, disruptive behavior is the result of student faculty interactions, and can be ameliorated by improved communication or behavioral strategies. In other cases, the behavior is symptomatic of more serious forms of mental illness.

Shelli

Going back to Shelli, she was a self-centered individual whose behavior had nothing to do with her religious beliefs. Nevertheless, we could link some of her responses to her religious background. She usually objected to what others and I had to say, and supported her own opinion by quoting verses from the Bible. Moreover, she could not accept "stories" describing non-observant pupils, schools or different ways of expression. She left the classroom abruptly if the subject discussed did not seem appropriate to her. Other classmates indicated that she behaved like that in other courses as well and overall, her grade average was low. Shelli was most probably scared of the openness and the straightforwardness of things said and, presumably, studying in a non-Haredi environment affected the way she responded. In addition to her inappropriate behavior, I was dismayed to find the following letter that Shelli had published on the course's internet forum. She also sent the same complaint letter to the head of the program without giving me a copy.

\subsection{Manifesto}

To: Dr. Lecturer from: Shelli

Today's lesson was no different from previous lessons. I want to protest against the level, the conduct of the teacher and the way the material is taught. There are discussions of observations, which may have been conducted without obtaining consent. The course pretends to be scientific and practical, but I personally do not see any scientifically organized or methodical instruction. The course is conducted in a theatrical and joking manner, what I would call worthless psychology.

The examples that the teacher presents from her illegal observations (which are probably derived from her will to use people unfairly for her tendentious research), resemble television shows and also include cursing. I consider this to be inappropriate for a religious university and unsuitable for the students and the forum (for your information, there are also Arab students who are shocked from the presentation of the material). I see that the written material (articles and bibliography) is indeed interesting, but I do not like the theatrical mode of teaching. For your information. 


\subsection{My Response}

This letter, addressed to me in public, was the last straw. I had actually been upset and bothered after every lesson. I kept asking myself what I could do to prevent, reduce or eliminate this kind of behavior and what actions I should take in order to lessen Shelli's reactions and maybe bring her closer to the material studied. Since the first part of the course dealt with the Ten Commandments for a dialogue (Isaacson, 2010), I deliberately used the Control and Rules method of "Be consistent" (Ibid). That is, whenever Shelli displayed one of her arrogant behaviors, I would continue treating her like the rest of the students. I would repeat the rules: come on time, do not use your cell phone or eat during the lectures, respect your colleagues, talk only when granted permission, etc. I also mentioned that students could always make an appointment to meet with me at my office.

Now I had to make a crucial decision. Should I continue with my educational principles despite the vulnerable situation I was in, my stance as a lecturer being ruined publicly? I deliberated as to whether I should even respond to such an insulting letter, which presented my academic degree but omitted my name. I finally decided to respond and wrote the following letter on the forum:

\section{Miss S.,}

I think that you are entitled to express your opinion, but your behavior and language in class and in your letter are neither appropriate nor respectful. It is your choice to study at this university and choose another course with another lecturer. Moreover, I am not sure that there is any reason for you to continue your studies in this course because it seems that it does not contribute to your academic skills, especially when you take facts out of context.

The supervisors at the Ministry of Education, as well as principals and teachers, approved this research. The course is based on a qualitative research study and observations have been conducted as is customary in every research. The course is deliberately presented in such a mode to enable the inexperienced teacher to fully understand how to conduct a class, especially at a time when violence is increasing in the educational system.

\subsection{The Students' Reactions}

Following my response, about ten students responded on the forum website. I think they felt an urge to defend me against such a public insult and had a perfect chance to express their feelings. I do not think that it is appropriate to quote the responses, but the content can be deduced from the titles: "You went too far!", "Respect", "To Miss Shelli and her future pupils", "What's up Shelli?", or just "Reply".

One student pointed out that he was "happy that the subject was significant for her" because she had reacted very strongly. However, he immediately stated the universal right of keeping a good reputation and about slander, referring to the use of words in Shelli's letter. Others talked about the importance of using one's name. Some criticized Shelli's behavior and connected it to the material learnt, namely "respect thy student", good manners, and planning a lesson for a whole class that consists of individuals that have different aspirations, sensitivities or attitudes. They discussed the essence of qualitative research which "is based on many observations" versus theoretical courses and tried to explain to Shelli that every observation of a researcher has to be approved and confirmed. "In real life when you stand helplessly in front of 40 pupils, you can use tools and techniques that can assist you instead of remembering an article's conclusions"...

They explained the role of the internet site that included articles and research material. They repeated one of the most important issues stressed during the lessons: "Stepping outside the box and open-minded thinking provide us with the chance to reflect upon ourselves as students and to examine the teachers we have had in life. What do we really remember out of their lessons?" Some stressed how much an account of a real experience had made the lesson worthwhile.

\subsection{No Comment}

Such comments encouraged and strengthened me. I felt that the responses had expressed my inner thoughts and feelings much better than I could have done and were actually a blessing in disguise. Moreover, I saw from the responses that the students had developed critical thinking. They had learned to distinguish between main and secondary issues, and actually acquired tools for handling challenging behaviors.

I now had to decide how to deal with Shelli. Shelli never responded to any of the opinions expressed in the forum and it was obvious that the students were waiting to see how I would deal with her, especially since the course dealt with conduct problems. The incident was not premeditated. Everyone was waiting to see if Shelli would show up and how I would solve the tension between us. Emotionally, as someone who had been hurt, I 
had a natural urge to be aggressive, but my inner voice advised me not to fall into the trap but to ignore Shelli's behavior and surprise them all.

That same week, I got an e-mail from the head of the TCP saying; "we had to talk due to a letter" she had received concerning my course. I kept asking the head of the department about the content of the letter, but she eventually decided to drop the subject and we never discussed the issue. I had mixed feelings. I still did not know for sure that the complaint letter had been from Shelli, or if her letter had triggered another student to express his/her dissatisfaction in writing. Moreover, if it was Shelli, I wondered as to what she wrote. I could not believe she would send the same complaint she had published on the forum to the head of the department. I felt threatened and lonely. I knew that even if the head of the department were on my side, it would be my task to cope with Shelli. I therefore had to try to resolve the delicate situation by myself.

After making sure that I have never done any harm or insulted Shelli in public, I decided to carry on with my beliefs, my theories and my methods of teaching regarding education. I taught the next lesson in the same manner and routine. I continued treating all the students with respect as usual, not changing my demands, conduct, or rules which I had stated in advance. I ignored Shelli, the situation and the students' expectations. I kept on teaching in the old same "theatrical way" and with the same mode of discussion. The students noticed that "no wind can really shake my trunk", and that "practice what you preach" is not just a saying but also a supporting pillar of teacher-student relationships that is based on reciprocal confidence and fulfillment of expectations.

\subsection{One Month Later}

Without any advance notice, a month or so later, Shelli approached my desk at the end of the lesson and handed me a copy of a letter. A few students stayed behind and stared curiously to see if there would finally be a confrontation between us. I realized that the letter was actually the same manifesto she had published on the forum website. She tried to explain in a low voice "she could not find my box" or "did not have my address". Then, I took the opportunity to explain to her (in the calmest voice I could manage) that "when one sends a complaint letter, a copy should be submitted to the person in question on the same day and not one month later". I could not help asking her how she dared express her thoughts in such a way on a forum of 80 students without trying to talk with me beforehand. I asked her whether I had harmed or insulted her in any way during the lessons, and she confirmed that I had never done so. Since she was an ultra-orthodox religious person, I finally suggested that she consult her Rabbi if embarrassing one in public is not one of the worst sins in Judaism.

There were a few students still standing around, witnessing this conversation, and they had no intention of leaving the room. When they started telling Shelli "you should be ashamed of yourself" etc., I stopped them immediately. I felt that it was not right to use the class against her. I never got an apology from Shelli (oral or written). To my surprise, she felt secure and free to attend my course and did not miss even one lesson. She kept asking questions that bothered her and when she raised her hand, I let her speak briefly. I noticed that my respectful tone was reflected in her voice.

Our last encounter was on the day of the exam. She smiled at me saying: "you were right. If one does not come to the course he cannot pass the exam". She took the exam, got 73, and wrote me an e-mail saying that she did not understand why she "got such a low grade" and that she wanted to sit and read the exam with me. Shelli did not interpret my attitude properly. I treated her with respect in class but I was not willing to spend any extra time with her, especially after such behavior. Therefore, I referred her to the exams unit, since they check the exams in a computerized mode. Shelli took the exam a second time, probably studied well, and got a 93.

\subsection{Epilogue \& Findings}

My interaction with Shelli was only in the context of the course's 12 meetings. Shelli behaved in an inappropriate way despite her colleagues' disapproval. She published a manifest in the course's forum web site denouncing the course objectives and issued a formal complaint letter to the Head of the Teacher Certificate Program. Shelli never came to talk to me in private during my office hours nor did she phone me. The only contact between us was before, during and after the lesson, the first "correspondence" on the forum and the last e-mail (concerning her grade regarding the exam). I decided not to invite her for a conversation as I always do with problematic students due to her negative, disrespectful and inappropriate attitude in class.

During the whole semester, I overcame my anger and continued to respect Shelli as I did with the rest of the students. In an academic institution, it is easy to get rid of a student like Shelli saying "she is not fulfilling the requirements of the course" or sending her to a disciplinary committee hearing. However, I was aware that the class was watching me carefully and I believed that it was an educational lesson they would never forget. Only 
with a positive approach can a teacher strengthen himself and the problematic student. Although keeping a positive approach is against human nature, a teacher should always take the high road and not stoop to such a low level as to take revenge on the student.

I did not seek a solution outside the class, nor did I talk to her supervisor or the head of the department. It became my challenge to resolve this confrontation with an educational message. During the summer vacation, I met some other lecturers who had a similar negative experience with Shelly and even wanted to recommend that she not get the teaching certificate. They even suspected that she might be mentally ill. I have to admit that I had mixed feelings concerning Shelli's achievements. At first, I felt a kind of satisfaction, when I saw her low grade compared to the other students. She deserved it. She had not listened and kept herself busy with other things, and in addition, expressed her thoughts loudly in the classroom. However, when she got a high grade on the second exam, I realized it was my role and duty to make every student succeed in spite and regardless of his or her behavior. Teacher-student relationship should not rely on a predicate of good conduct-good grade, but on certain educational objectives that the teacher believes in.

I ignored Shelli's behavior and continued to relate to her as a "regular" student while reiterating the rules that are expected in an academic course. Her conduct gave me the opportunity to demonstrate a teacher's response in real-time. The students observed my reaction to her in the framework of the course that in effect, deals with discipline disorder. As a result, Shelli eventually accepted the method she had rejected so firmly.

\section{Conclusion and Implications}

This article is an ex post facto research (Simon \& Goes, 2013), case study or an object of study (Stake, 1995), and an exploration of a "bounded system" (Smith, 1979) over 12 weeks of a semester-long academic course. The focus was an investigation of the behavior of an individual, a student who, because of her unique religious background, was an interesting candidate for an intrinsic case study. I analyzed the case through direct interpretation, looking at a single instance and drawing meaning from it without looking for multiple instances. McKeachie and Svinicki (2006) present an overview of strategies for effective teaching in the college classroom. In addition to presenting clear, organized lectures, and being fair about grading policies, the use of active learning strategies and interactive techniques has been shown to promote learning and classroom civility. It is also useful to establish rituals for the beginning and ending of class so students know what to expect. In this context, there are a number of characteristic active parameters concerning the handling of Shelli's case.

1). Acting persistently. Although Shelli behaved in an appalling way, I did not let myself become angry or insult her in public. Burnett (2000) suggests that teachers be aware of their own assumptions about conflict and their approaches to it. The first step in Burnett's model for conflict resolution is identifying the problem without blame. Accordingly, Shelli got neither an irritated response nor an accusation, nor was she called in for questioning. Instead, I was very patient and restrained with her and waited until she understood the course's requirements and desired behavior code in order to succeed. Holton (1999) asserts that part of identifying a solution includes developing a positive attitude, establishing ground rules, identifying interests of parties and identifying alternatives. Holton stresses that in order to manage a classroom conflict effectively, college faculty needs to be able to identify and analyze the problem. Shelli behaved as a rebel. She rebelled against the style of the course without even listening to the context in which things were said. As the typical opponent, she spoke loudly and tried to have an effect on her environment. However, Shelli did not gain any sympathy from her classmates; instead, she aroused resentment.

2). Modeling as a tool for teaching. The students watched a "real-time" solution during the course. Through my reactions, they were better able to comprehend the appropriate method for this type of misbehavior. Green, Mitchell and Taylor (2011) believe that mentoring through modeling gives teachers the opportunity to be motivational tools in the lives of their students. Their research shows for example, that elementary grade pupils become more motivated to produce quality works of art through cross-age mentoring (high school pupils) in the art classroom. The study also demonstrates that a modeling behavior of a teacher, such as reenacting a behavior of an artist under study, will result in a more productive environment of creativity and success while also grounding the children in the material. It is especially important to note that a generalization can be taken from all of the research models concerning mentoring. This generalization is that both the mentor and the mentored gain from the experience. Whether the method is cross-age or peer mentoring, the result is the bond that is forged between two individuals who are focused on one main goal. Such a bond facilitates learning and reduces conflict.

Watson and Bradley (2009) affirm that instructional strategies are merely listed and explained in teacher education courses. Students rarely have the opportunity to see these strategies applied first-hand until they 
become teachers. There is no better way to teach secondary instructional strategies to pre-service teachers than by modeling these strategies directly when they happen, using teacher education content.

Loughran and Berry (2005) briefly outline the university's conception of episteme and phronesis, and then explore the university's views of explicit modeling, which operates concurrently at two levels. At one level, it is about teacher educators "doing" in their practice what they expect their students to do in their teaching. This means they must model the use of engaging and innovative teaching practices, rather than deliver information about such practice through traditional approaches. At another level, there is a need to offer student-teachers access to the pedagogical reasoning, feelings, thoughts and actions that accompany practice across a range of teaching and learning experiences. Teacher educators make such access available in a variety of ways: think-aloud, journaling, discussions during and after class with groups and individuals (similar to the active forum in the course's site), questioning, probing, and inquiry, all of which are created through pedagogic interventions during teaching and debriefing of shared teaching and learning experiences.

3). Using the bypass procedure (Isaacson, 2010). This method stems from care, empathy and reinforcement of the student. This creative method facilitates learning even when there are disruptions in the class. The teacher must ignore the negative behavior by unexpectedly connecting it to an educational aspect. Instead of admonishing a student who is talking loudly without permission, the teacher should reinforce some of his words but immediately remind him (and the other students) that he should speak only when allowed. When Shelli expected an angry reaction or punishment for her unruly behavior, she got a surprising response instead. Thus, she learnt a double lesson, both informative and behavioral. Students find out very quickly that such a teacher is not quick to punish, but respectful, and they have no choice but to join the positive learning environment. In addition, as Kottler and Zehm (2005) argue, students consider equal treatment of students to be an important element of teacher caring. Teachers who forgive students for their mistakes give students the benefit of the doubt and provide second chances when appropriate.

I have also used the journalist method (Isaacson, 2010) which corresponds to Explicit Boundaries. Its purpose is to produce authoritativeness by speaking in short sentences, like headlines in a newspaper and in addition, to talk briefly and concisely and mention only main details. This way, Shelli and the other students immediately understood that the teacher is not a friend, but still relates respectfully to class conversations without being drawn into any arguments. Nash (2009), observed teachers over the years and found a common thread that runs through the classrooms of the most effective teachers. He found that effective teachers are those who are habitually calm and possess a great deal of self-confidence, handle discipline problems firmly, quietly and without disrupting the flow of process in the classroom. Despite the unique environment and personality of teacher and student, the lessons CAN be generalized because the behaviors the student engaged in on this campus are hardly unique at college.

Student conflicts are an inevitable part of classroom life. Teachers however, can, prevent most conflicts from escalating into hostile arguments among students. Proactive strategies exist to help teachers prevent and safely manage student confrontations (Meese, 1997). Fuchs-Shabtai and Blank (2004) declare that there is no contradiction between warm and loving parenting and defining boundaries (p. 97). The secondary title of their book states: "knowing to hug, knowing to demand", meaning that encouragement and demand should be used hand in hand. We have seen that Shelli's case was resolved with the use of consistency and boundaries. These two techniques require repetition and routine. In order to maintain order and obedience or acquire a learning habit, a teacher must continuously remind the students of the rules and regulations and demand that they be implemented. It seems that both children and adults need repetition in order to prevent misconceptions and misunderstandings. Boundaries facilitate learning and provide security. Most disciplinary problems (especially at the beginning of the school year or a course) stem from testing the teacher or testing limits. Therefore, teachers must always state explicit rules regarding acceptable modes of behavior and allow freedom only within those set boundaries. Caring and supportive student-teacher relationships can contribute to positive outcomes for students at risk, preventing academic failure, social isolation, and school dropout.

\section{References}

Baker, J. A., Grant, S., \& Morlock, L. (2008). The teacher-student relationship as a developmental context for children with internalizing or externalizing behavior problems. School Psychology Quarterly, 23(1), 3-15. http://dx.doi.org/10.1037/1045-3830.23.1.3

Barnett, B., Alesha, D., \& Alan, W. (2010). Preparing to Lead an Effective Classroom: The Role of Teacher Training and Professional Development Programs. Center for Teaching Quality. Retrieved from http://www.teachingquality.org 
Baumel, S. D. (2005). Sacred speakers: Language and culture among the Haredim in Israel. New York: Berghahn Books.

Belton, L. (2008). What our teachers should know and be able to do: A student's view. Educational Leadership, 54(1), 66-68.

Bogdan, R., \& Biklen, S. K. (1982). Qualitative research methods for education. Boston: Allyn and Bacon.

Boice, B. (1996). Classroom Incivilities. Research in Higher Education, 37(4), 453-486. http://dx.doi.org/10.1007/BF01730110

Bradley, D. F., Pauley, J. A., \& Pauley, J. F. (2005). Effective classroom management: Six keys to success. Rowman and Littlefield Education.

Burnett, E. M. G. (2000). Conflict resolution: Four steps worth taking. Social Studies and the Young Learner, 12(3), 20-23.

Cohen, L., Manion, L., \& Morison, K. (2000). Research Methods in Education. London: Routledge Falmer. http://dx.doi.org/10.4324/9780203224342

Creswell, J. W. (1998). Qualitative inquiry and research design: Choosing among five traditions. Thousand Oaks, CA: Sage.

Decker, D. M., Dona, D. P., \& Christenson, S. L. (2007). Behaviorally at-risk African American students: The importance of student-teacher relationships for student outcomes. Journal of School Psychology, 45(1), 83-109. http://dx.doi.org/10.1016/j.jsp.2006.09.004

Fuchs-Shabtai, O., \& Blank, S. (2004). Good parents. Or Yehuda: Kinneret, Zmora- Bitan [in Hebrew].

Gordon, S. C., Dembo, M. H., \& Hocevar, D. (2007). Do teachers' own learning behaviors influence their classroom goal orientation and control ideology? Teaching and Teacher Education, 23(1), 36-46. http://dx.doi.org/10.1016/j.tate.2004.08.002

Green, D., Mitchell, T., \& Taylor, P. (2011). Mentoring in the Art Classroom. Improving Schools, 14(2), 117-129. http://dx.doi.org/10.1177/1365480211410452

Greer, R. D. (2002). Designing teaching strategies: An applied behavior analysis systems approach. Amsterdam, San Diego Academic Press.

Heilman, S. C. (2000). Defenders of the faith: Inside ultra-Orthodox Jewry (2nd ed.). Berkeley: University of California Press.

Holton, S. A. (1999). After the Eruption: Managing conflict in the classroom. New Directions for Teaching and Learning, 77, 59-68. http://dx.doi.org/10.1002/tl.7706

Isaacson, A. (2010). Defining the Ideal Teacher: Productive Dialogue in Schools in Israel. Educational Practice and Theory, 32(2), 57-85. http://dx.doi.org/10.7459/ept/32.2.05

Kottler, J. A., Zehm, S. J., \& Kottler, E. (2005). On Being A Teacher (3rd ed.). Thousand Oaks: Corwin.

Lichtmann, M. R. (2010). Community College as Liminal Space. New Directions for Community Colleges, 151, 17-28. http://dx.doi.org/10.1002/cc.412

Loughran, J., \& Berry, A. (2005). Modeling by teacher educators. Teaching and Teacher Education, 21(2), 193-203. http://dx.doi.org/10.1016/j.tate.2004.12.005

Marzluf, P. P. (2009). Writing Home-Schooled Students into the Academy. Composition Studies, 37(1), 49-66.

McKeachie, W., \& Svinicki, M. (2014). McKeachie's Teaching Tips. Belmont, Ca: Wadsworth.

McNaughton-Cassill, M. E. (2013). Is it Incivility or Mental Illness? Understanding and Coping with Disruptive Student Behavior in the College Classroom. Journal of Effective Teaching, 13(2), 94-108.

Merriam, S. B. (1998). Qualitative research and case study applications in education. San Francisco: Jossey-Bass.

Meese, R. L. (1997). Student fights: Proactive strategies for preventing and managing student conflicts. Intervention in School and Clinic, 33(1), 26-29. http://dx.doi.org/10.1177/105345129703300105

Nash, R. (2009). The Active Teacher: Practical Strategies for Maximizing Teacher Effectiveness. Thousand Oaks: Corwin.

Olsen, J. (2001). Dealing with disruptive students in the classroom. London: TES. 
Schelfhout, W., Dochy, F., Janssens, S., Struyven, K., Gielen, S., \& Sierens, E. (2006). Educating for learning-focused teaching in teacher training: The need to link learning content with practice experiences within an inductive approach. Teaching and Teacher Education, 22(7), 874-897. http://dx.doi.org/10.1016/j.tate.2006.04.003

Schworm, S., \& Renkl, A. (2007). Learning argumentation skills through the use of prompts for self-explaining $\begin{array}{llll}\text { examples. Journal of Educational Psychology, } & \text { 99(2), }\end{array}$ http://dx.doi.org/10.1037/0022-0663.99.2.285

Scott, J. L., \& Teale, W. H. (2010). Redesigning teacher education programs: How high can we fly? The Reading Teacher, 64(4), 291-293. http://dx.doi.org/10.1598/RT.64.4.11

Silverman, D. (2000). Doing qualitative research: A practical handbook. Thousand Oaks, CA: Sage.

Simon, M. K., \& Goes, J. (2013). Dissertation and Scholarly Research: Recipes for Success. Seattle, WA: Dissertation Success LLC.

Skinner, E. A., \& Belmont, M. J. (1993). Motivation in the classroom: Reciprocal effects of teacher behavior and student engagement across the school year. Journal of Educational Psychology, 85(4), 571-581. http://dx.doi.org/10.1037/0022-0663.85.4.571

Smith, L. (1979). An evolving logic of participant observation, educational ethnography, and other case studies. In L. Shulman (Ed.), Review of research in education (pp. 316-377). Itasca, IL: F. E. Peacock.

Stake, R. E. (1994). Identification of the case. In N. K. Denzin, \& Y. S. Lincoln (Eds.), Handbook of qualitative research (pp. 236-247). Thousand Oaks, CA: Sage.

Stake, R. E. (1995). The art of case study research. Thousand Oaks, CA: Sage.

Sykes, G., Bird, T., \& Kennedy, M. (2010). Teacher Education: Its problems and some prospects. Journal of Teacher Education, 61(5), 464-476. http://dx.doi.org/10.1177/0022487110375804

Valentine, S. J. (2011). The Professionalization of Independence: New Tensions and Opportunities for Independent School Teachers. Independent School, 70(4).

Watson, S. W., \& Bradley, J. F. (2009). Modeling Secondary Instructional strategies in a teacher education class. Education, 130(1), 3-15.

\section{Note}

Note 1. School of Education, Bar Ilan University, Ramat Gan 5290002, Isreal. E-mail: isaacsa@biu.ac.il

\section{Copyrights}

Copyright for this article is retained by the author(s), with first publication rights granted to the journal.

This is an open-access article distributed under the terms and conditions of the Creative Commons Attribution license (http://creativecommons.org/licenses/by/3.0/). 